\title{
Autoimmune synaptic protein encephalopathy syndromes and the interplay between mental health, neurology and immunology
}

\author{
Gregory S. Day and Harry E. Peery
}

\section{University of Toronto, McMaster University}

Indirect evidence supporting the organic underpinnings of mental illness has accumulated over the past five decades, driven by advances in neuropharmacology, neurochemistry, neuroimaging, and neuropathology, and by expanding knowledge of the structural and ultra-structural changes that occur within the brains of patients with behavioural and affective symptoms. ${ }^{1}$ Yet, despite a growing body of evidence, a distinction continues to be drawn between psychological anomalies of the mind and organic disorders of the nervous system. The recent isolation and characterization of pathogenic autoantibodies within the blood and cerebrospinal fluid of patients with symptoms and signs commonly associated with 'mental illness' raises new questions about the origins and pathogenesis of behavioural and affective disorders, providing a timely and welcome challenge to the ideology that divides mental illness and neurological disorders.

\begin{tabular}{|c|c|c|}
\hline ASPES & Antibody Target & Common Clinical Features \\
\hline $\begin{array}{l}\text { Anti-NMDA-receptor } \\
\text { encephalitis }\end{array}$ & $\begin{array}{l}\text { NMDA receptor: } \\
\text { GluN1/GluN2B } \\
\text { subunits }\end{array}$ & $\begin{array}{ll}\text { - } & \text { Psychoses, behavioural/affective symptoms } \\
\text { - } & \text { Encephalopathy } \\
\text { - } & \text { Hyperkinetic movements } \\
\text { - } & \text { Seizures } \\
\text { - } & \text { Central hypoventilation and autonomic instability }\end{array}$ \\
\hline $\begin{array}{l}\text { Anti-AMPA-receptor } \\
\text { encephalitis }\end{array}$ & $\begin{array}{l}\text { AMPA receptor: } \\
\text { GluR1/GluR2 subunits }\end{array}$ & $\begin{array}{l}\text { - } \quad \text { Psychoses, behavioural/affective symptoms } \\
\text { - } \quad \text { Encephalopathy }\end{array}$ \\
\hline $\begin{array}{l}\text { Anti-GABA }{ }_{B} \text {-receptor } \\
\text { encephalitis }\end{array}$ & $\mathrm{GABA}_{\mathrm{B}}$ receptor & $\begin{array}{ll}\text { - } & \text { Psychoses, behavioural/affective symptoms } \\
\text { - } & \text { Encephalopathy } \\
\text { - } & \text { Seizures (early in disease) }\end{array}$ \\
\hline $\begin{array}{l}\text { Anti-glycine-receptor } \\
\text { encephalitis }\end{array}$ & Glycine receptor & $\begin{array}{l}\text { - } \quad \text { Psychoses, behavioural/affective symptoms } \\
\text { - } \quad \text { Encephalopathy }\end{array}$ \\
\hline \multirow[t]{2}{*}{$\begin{array}{l}\text { Anti-potassium channel- } \\
\text { associated-complex } \\
\text { encephalitis }\end{array}$} & LGI1 & $\begin{array}{ll}\text { - } & \text { Psychoses, behavioural/affective symptoms } \\
\text { - } & \text { Encephalopathy } \\
\text { - } & \text { Hyponatremia } \\
\text { - } & \text { Seizures (brief tonic-myoclonic seizures) }\end{array}$ \\
\hline & Caspr2 & $\begin{array}{l}\text { - } \\
\text { - } \\
\text { - } \\
\text { - } \\
\text { Periphcephalopathy } \\
\text { syndrome) }\end{array}$ \\
\hline Anti-GAD encephalitis* & GAD & 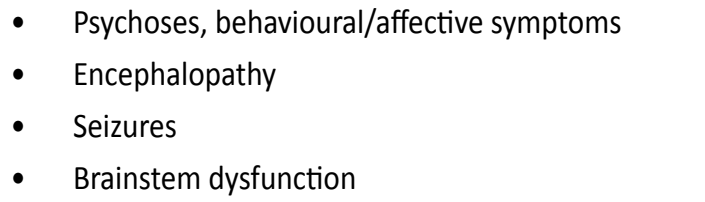 \\
\hline
\end{tabular}

Table 1: ASPES defined

Abbreviations: NMDA $=$ $\mathrm{N}$-methyl-D-aspartate; Glu = glutamate; AMPA $=\alpha$-amino-3-hydroxy5-methylisoxazole-4proprionic acid; GABAB = gamma-aminobutyric acid-B; LGI1 = leucinerich glioma-inactivated 1 ; Caspr2 $=$ contactinassociated protein-like 2; GAD = glutamate decarboxylase

*The role of anti-GAD antibodies in ASPES requires clarification; unlike other ASPES, anti-GAD antibodies are directed against intracellular antigens and are frequently

described in

association with other autoantibodies (most notably GABAB) 
C Autoimmune synaptic protein encephalopathy syndromes (ASPES) encompass a growing group of clinicallyrecognizable diseases associated with psychiatric symptoms, progressive neurologic dysfunction, and response to immunosuppressant therapies. Expanding work in neuroimmunology has only begun to decipher the relationship between individual syndromes and circulating autoantibodies, allowing syndromes historically defined by the absence of a known etiologic agent (i.e., 'demonic possession,' 'idiopathic encephalitis,' 'limbic encephalitis') to be defined by the presence of a specific pathogenic antibody. To date, a number of receptor-specific autoantibodies have been described in association with ASPES (Table 1). ${ }^{2,3}$ Of these, the syndrome associated with autoantibodies against central nervous system $\mathrm{N}$-methyl$\mathrm{D}$-aspartate (NMDA) receptors remains the most prevalent and best-characterized.

Patients with anti-NMDA-receptor encephalitis (ANMDARE) commonly present with abrupt-onset symptoms including hallucinations, delusions, apathy, fear, depression, memory loss, and confusion/encephalopathy ${ }^{4-6}$ - analogous to symptoms reported in healthy adults exposed to the NMDA receptor blocking agent, ketamine. ${ }^{7}$ For this reason, patients presenting with ANMDARE are often assessed by psychiatrists and other mental health professionals. ${ }^{4}$ Left untreated, increasingly severe symptoms may emerge, including hyperkinetic movement disorders (commonly oral-facial dyskinesias), seizures, and central hypoventilation with autonomic instability. ${ }^{4-6}$ Seventyfive percent of patients require admission to intensive care units for cardiorespiratory support. ${ }^{5}$ The diagnosis is confirmed by detection of autoantibodies directed against the GluN1- and/or GluN2B-subunits of the ionotropic glutamate-binding NMDA receptor complex using standard indirect immunofluorescence techniques, or more preferably in combination with an adapted cell-based assay using tissue culture cells overexpressing transfected complementary DNA representing the single or assembled GluN1-GluN2-subunits. ${ }^{2}$ NMDA receptors are found in highest concentrations within the hippocampi, forebrain, basal ganglia, spinal cord, and cerebellum, ${ }^{4}$ mediating a critical role in synaptic plasticity through regulation of intracellular calcium influx. Thus, autoantibody-receptor binding may preferentially affect structures responsible for memory, personality, movement, and respiratory drive, provoking the unique constellation of symptoms and signs that characterizes ANMDARE by inducing receptor internalization and/or cellular apoptosis ${ }^{4,8}$
Much has been written concerning putative disease pathogenesis since the first clinical reports of ANMDARE were published in 2007. ${ }^{9}$ Early reports of ovarian teratomas in $59 \%$ of cases led to speculation that ANMDARE developed as a consequence of an immune response directed against NMDA receptors expressed on tumour cell surfaces. ${ }^{9}$ More recent case series suggest that a tumour is detected in $38 \%$ of patients overall; ${ }^{5}$ thus, while tumours may go undiagnosed in some patients, additional tissue sites are likely involved in disease pathogenesis. The role of host and environmental factors in triggering and promoting development of autoimmunity is the focus of ongoing research. ${ }^{2}$

Beyond informing our nascent knowledge of disease pathogenesis, expanding clinical experience has increased our understanding of disease prevalence. The accrual of 577 patients by a single research group over a five-year period ${ }^{5}$ asserts that ANMDARE is not a rare disease, but rather a rare diagnosis. The diagnosis may be especially rare in patients labelled with 'mental illness.' In a single neuropsychiatric centre, anti-NMDA-receptor autoantibodies were detected in $7.8 \%(4 / 51)$ of patients with a diagnosis of schizophrenia/ schizoaffective disorder, ${ }^{10}$ emphasizing the importance of considering the diagnosis in all patients with progressive behavioural/affective disturbances without a known etiology.

Appropriate treatment of patients with ANMDARE demands prompt initiation of immunosuppressant therapies. Consensus recommendations derived from case experience support the use of increasingly toxic therapies, beginning with high-dose corticosteroids and/ or intravenous immunoglobulins; cyclophosphamide and the anti-CD-20 monoclonal antibody, rituximab, are recommended for those who fail to respond to first-line therapies. ${ }^{6}$ With optimal treatment, the prognosis is good: over $75 \%$ are alive with minimal or no disability within two years of diagnosis. ${ }^{5}$ Delays in treatment or under-treatment, however, are associated with longer times to improvement, longer ICU stays, lower chances of recovery, and a higher risk of relapse. ${ }^{5,6}$ Mortality is reported in $6 \%$ of cases. ${ }^{5}$ For these reasons, it is critical to promote early diagnosis and treatment of ANMDARE; it is also critical to ensure that longitudinal care is provided within tertiary care centres with experience in the multidisciplinary management of ASPES.

The discovery of a highly-treatable group of diseases presenting with behavioural/affective symptoms and progressive neurological dysfunction provides a 
well-timed opportunity to strengthen clinical and research partnerships between the fields of psychiatry and neurology. Further work considering ASPES will be best performed by clinicians and researchers working together to ensure that patients with 'mental illness' receive appropriate diagnostic investigations and subsequent treatments, leaving the dogma that divides mental illness and neurological disease where it belongs: in the past.

\section{References}

1. Lautenschlager NT, Forstl H. Organic psychosis: Insights into the biology of psychosis. Curr Psychiatry Rep. 2001;3:319-25.

2. Peery HE, Day GS, Dunn S, Fritzler MJ, Pruss H, De Souza C, et al. Anti-NMDA receptor encephalitis. The disorder, the diagnosis and the immunobiology. Autoimmun Rev. 2012;11(12):863-72.

3. Lancaster E, Martinez-Hernandez E, Dalmau J. Encephalitis and antibodies to synaptic and neuronal cell surface proteins. Neurology. 2011;77(2):179-89.

4. Dalmau J, Gleichman AJ, Hughes EG, Rossi JE, Peng X, Lai M, et al. AntiNMDA-receptor encephalitis: Case series and analysis of the effects of antibodies. Lancet Neurol. 2008;7(12):1091-8. Epub 2008 Oct 15.

5. Titulaer MJ, McCracken L, Gabilondo I, Armangue T, Glaser C, lizuka T, et al. Treatment and prognostic factors for long-term outcome in patients with anti-NMDA receptor encephalitis: An observational cohort study. Lancet Neurol. 2013;12(2):157-65.

6. Dalmau J, Lancaster E, Martinez-Hernandez E, Rosenfeld MR, Balice-Gordon R. Clinical experience and laboratory investigations in patients with antiNMDAR encephalitis. Lancet Neurol. 2011;10(1):63-74.

7. Pomarol-Clotet E, Honey GD, Murray GK, Corlett PR, Absalom AR, Lee $M$, et al. Psychological effects of ketamine in healthy volunteers. Phenomenological study. Br J Psychiatry. 2006;189:173-9.

8. Hughes EG, Peng X, Gleichman AJ, Lai M, Zhou L, Tsou R, et al. Cellular and synaptic mechanisms of anti-NMDA receptor encephalitis. J Neurosci. 2010;30(17):5866-75.

9. Dalmau J, Tuzun E, Wu HY, Masjuan J, Rossi JE, Voloschin A, et al. Paraneoplastic anti-N-methyl-D-aspartate receptor encephalitis associated with ovarian teratoma. Ann Neurol. 2007;61(1):25-36

10. Tsutsui K, Kanbayashi T, Tanaka K, Boku S, Ito W, Tokunaga J, et al. AntiNMDA-receptor antibody detected in encephalitis, schizophrenia, and narcolepsy with psychotic features. BMC Psychiatry. 2012;12:37.

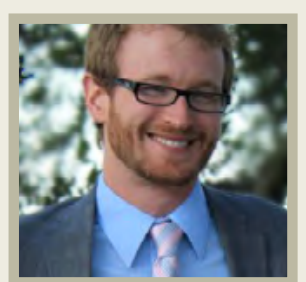

\section{Gregg Day}

Gregg Day is in his final year of neurology residency at the University of Toronto, and is pursuing postgraduate training in neurodegenerative and antibody-mediated brain diseases. He is a founding member of the Anti-NMDA Receptor Foundation, and serves as the Clinical Director. His research focuses on characterizing the clinical presentation and improving treatment of patients with antibody-mediated brain diseases.

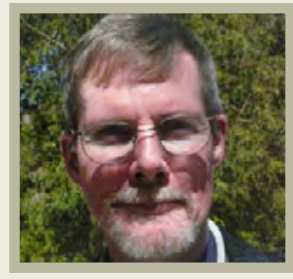

\section{Harry Peery}

Harry Peery took the long road to his PhD, working as a critical care nurse before returning to academia. Harry successfully defended his PhD in neuropharmacology in 2013 at the University of Saskatchewan, and is engaged in post-doctoral research at Atomic Energy of Canada, Ltd, through McMaster University. Harry is a founding member of the Anti-NMDA Receptor Foundation, and serves as the Research Director. His research focuses on deciphering the pathogenesis of antibody-mediated brain disease. 